\title{
THE ABILITY OF CRITICAL THINKING OF ELEMENTARY SCHOOL STUDENTS USING A GRAPHIC ORGANIZER INSTRUMENT
}

\author{
Otang Kurniaman'1), Eddy Noviana' ${ }^{2)}$, Munjiatun ${ }^{3)}$ \\ Universitas Riau, Indonesia \\ Email: otang.kurniaman@lecturer.unri.ac.id ${ }^{1}$,eddy.noviana@lecturer.unri.ac.id²), \\ munjiatun@lecturer.unri.ac.id
}

Submit: 29 April 2020, Revisi: 21 Juli 2020, Approve: 11 November 2020

\begin{abstract}
Critical thinking is an emphasis on the 2013 curriculum, as an activity in learning that must be done by the teacher for that it needs analysis to describe student abilities. Graphic organizer instrument is a learning medium as a concept mapping of students' thinking in reading comprehension. This research uses descriptive quantitative survey research method with a sample of 318 elementary school students who are in public schools in the Tampan subDistrict, Pekanbaru, Riau Province. The results of the study found that out of 18 schools with a sample of 318 students there were 9 schools that received the 'not good' category, 9 schools that received the 'less good' category. Viewed from the critical thinking indicator, it turns out that the student's ability score reaches 23 with the category of underperformance or very low under the standard of mastery learning. It can be concluded that the ability of students in critical thinking is still very low and needs government attention to improve teacher learning.
\end{abstract}

Keyword: critical thinking, instrument graphic organizer.

Pengutipan: Otang Kurniaman, dkk. (2020). The Ability of Critical Thinking of Elementary School Students Using a Graphic Organizer Instrument. JMIE: Journal of Madrasah Ibtidaiyah Education, 4(2), 2020, 206-216. jmie.v4i2.166.

Permalink/DOI: http://dx.doi.org/10.32934/jmie.v4i2.166 


\section{INTRODUCTION}

In accordance with the 2013 curriculum that was implemented in elementary schools, it was very demanding that students critical thinking in every lesson given by the teacher. The teacher's ability to teach is also required to develop critical thinking as HOTS (Higher Order Thinking Skill) learning. HOTS is the one that is demanded by Indonesian national education in accordance with as stipulated in the Regulation of the Minister of Education and Culture of the Republic of Indonesia Number 22 Year 2016 regarding the standard process of Basic and Secondary Education that knowledge is obtained through activities "Remembering, understanding, applying, analyzing, evaluating and create ". This means that every student starting from Elementary Education to Secondary Education is required to produce graduates or products that have the ability to remember, understand, apply, analyze, evaluate and create, in other words, "Higher Order Thinking Skill" or HOTS (Kemendikbud, 2018).

The capacity to suppose critically, lead a person to behave a ways and carefully (Haryani, 2011), give an explanation for the reasons, and remedy problems (Indrawatiningsih, 2018). Someone who's considerate will now no longer make a selection with out thinking about the context of the trouble at hand. Every selection taken is observed via way of means of logical reasons. Logically a motive can enhance the first-rate of selections taken. On the opposite hand, essential questioning abilities can enhance information of clinical concepts (Asmawati, 2015; Trisdiono, Siswandari, Suryani, \& Joyoatmojo, 2019).

The development of students 'abilities in critical thinking is influenced by the intensity of students' reading because reading is complex learning that includes metacognitive activities as a thought process (Munjiatun, et al, 2015). In addition to decoding skills, readers must also have skills in understanding meaning. Understanding the meaning takes place through various levels, ranging from the level of literal understanding to interpretive, creative, and evaluative understanding. Thus, it can be said that reading is a combination of perceptual and cognitive processes (Kurniaman \& Noviana, 2016). Learning done by the teacher is crucial in optimizing the process of critical thinking done by students for that is done using graphic media organizer as a concept mapping of thinking in reading comprehension, because the graphic organizer is a visual communication tool that uses visual symbols to express ideas and concepts, to convey meaning (Kurniaman \& Charlina, 2018). Critical thinking as an active process of deliberate reflection that makes sense that focuses on deciding what needs to be done by responding to a case (Sobkowiak, 2016) in the 2013 curriculum, teachers are required to develop critical thinking by giving HOTS tests as a solution to practice thinking skills high level (Malik, et al, 2018; Kurniaman, et al, 2019). In accordance with the demands of 21stcentury skills students must have intelligence competencies in responding to environmental responses.

The current era of globalization is critical thinking is an important skill in life and the 
world of work and has a role in improving human quality (Khasanah, et al, 2017; Anazifa \& Djukri, 2017; Abed, et al, 2015; Wartono, et al, 2018; Bustami, et al, 2018). The development of critical thinking in elementary school students can improve learning outcomes that emphasize making the right decision to solve the problem (Bustami, 2009; Ku, 2009; Fisher, 2009; Carter, et al, 2016). Critical thinking is a part of high level skills that must be developed by being taught in the learning process (Murnaka, et al, 2019) because elementary school students are still in the golden age stage which must be optimized in their development (Kurniaman \& Noviana, 2013), for that the 2013 curriculum used in education in Indonesia places emphasis on critical thinking skills. Therefore this research is needed in need of an analysis of the ability of elementary school students today to provide the next action that must be done by education experts.

\section{METHOD}

The method of research conducted using descriptive quantitative survey research is a research method that shows the phenomena that exist and provides a picture by using numbers as a reinforcement of research results that will be described in words in giving a picture of the numbers that appear in research (Sugiono, 2015). Population is a generalization area consisting of objects or subjects that have certain qualities and characteristics determined by researchers to be studied and then drawn conclusions (Grabe \& Stoller, 2011).

The framework of thinking in this study is in accordance with the method to be studied, using descriptive quantitative methods with the use of research instruments in the form of tests to measure the critical thinking abilities of elementary school students, with instruments in the form of graphic organizers so that student thinking can be mapped makes it easier to analyze it. The flow of this research activity is in accordance with the figure below.

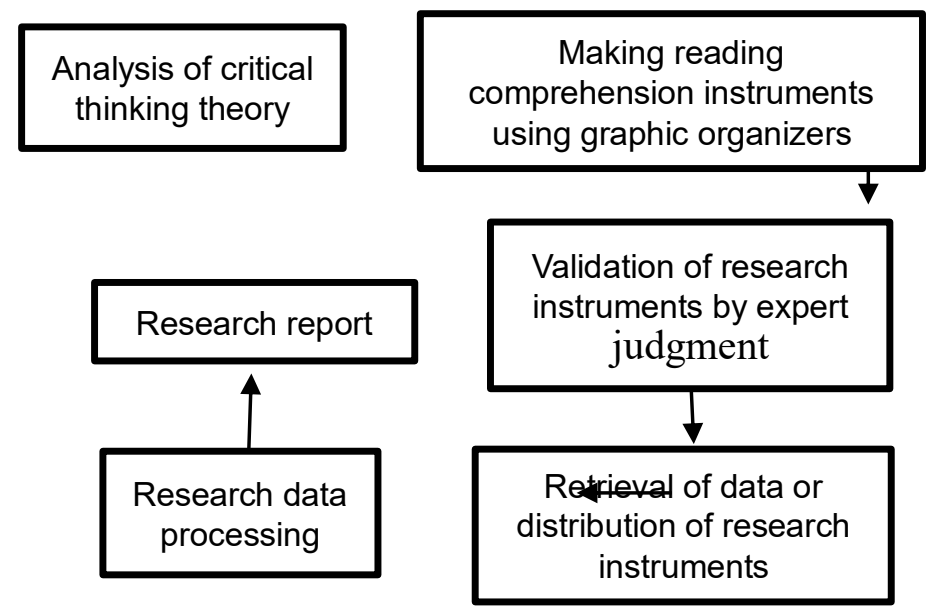

Figure 1. Research Flow 
Before conducting research, first of all, analyze the theory of critical thinking so that it can make research instruments by measuring the ability of elementary school students, based on indicators in reading comprehension by using a graphic organizer as a medium to measure student abilities, the graphic organizer makes it easy to analyze student abilities because teachers teach maps the concept presented in accordance with the text that has been read. The research instrument was validated by experts or expert judgment then data retrieval was in accordance with a predetermined sample of public schools in Tampan sub-district of Pekanbaru. The data that has been obtained is processed in accordance with the indicators of critical thinking, then makes a research report. Will be seen in table 1 indicators in reading.

Table 1. Critical Thinking Indicators in Reading

\begin{tabular}{cl}
\hline No & \multicolumn{1}{c}{ Assessment Indicator } \\
\hline 1 & Identify the initial problem \\
2 & Understanding Reasoning \\
3 & Identify and interpret statements and ideas \\
4 & Identifying conclusions \\
\hline
\end{tabular}

Fill in the chart/column below correctly based on the text you have read!

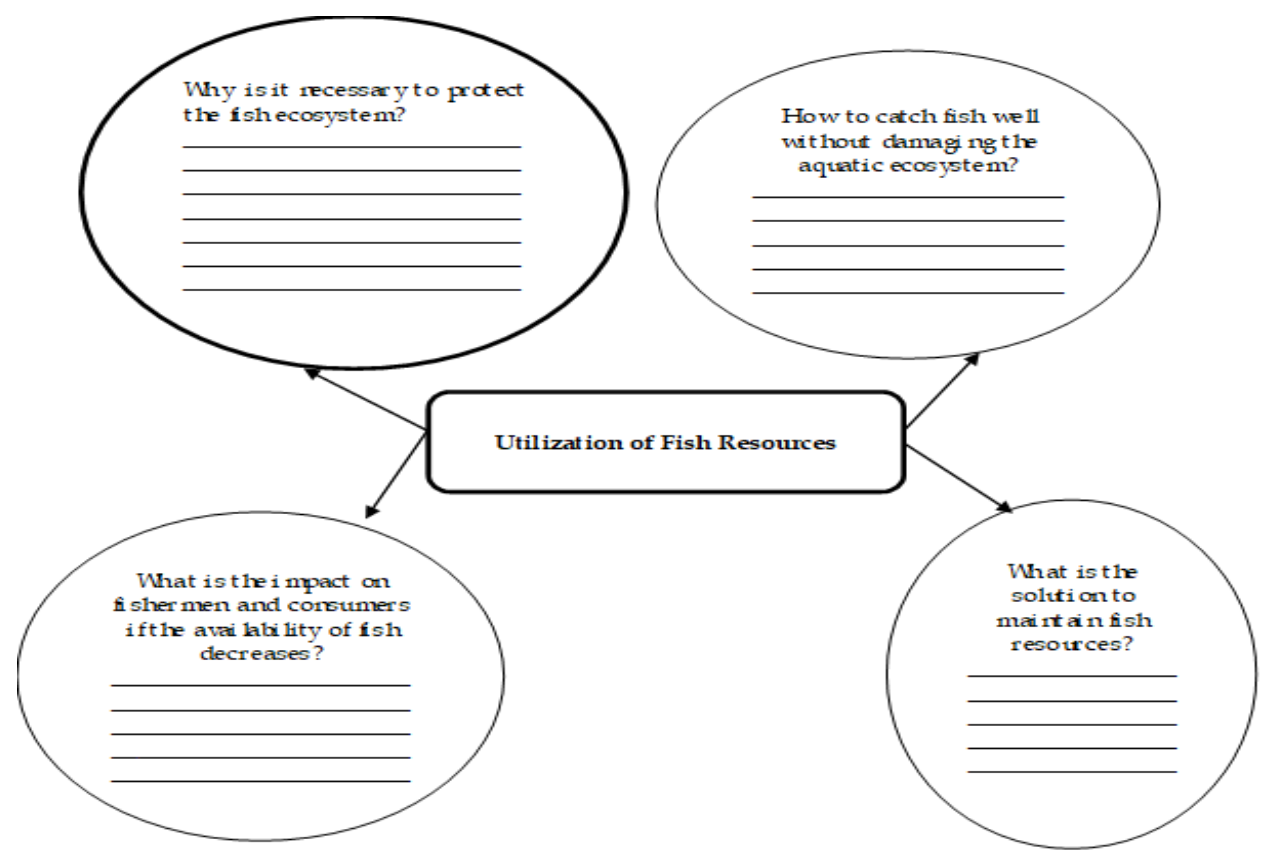

Graphic 1. Organizer Instrument 
The population in this study consisted of 18 elementary schools in Tampan subDistrict Pekanbaru with research subjects in grade IV elementary schools with a population of 2629 people. (Riduwan, 2015) Determination of the sample of this study amounted to 318 people with a precision level of $5 \%$ random sampling. Data analysis techniques by classifying data using formulas.

$$
P=\frac{\mathrm{F}}{\mathrm{N}} \times 100
$$

Information:

$\mathrm{P}=$ Critical Thinking Ability

$\mathrm{F}=$ Frequency of Score Obtained

$\mathrm{N}=$ Ideal Amount

Table 2. Students' Critical Thinking Ability

\begin{tabular}{cc}
\hline Interval & Category \\
\hline $81-100$ & Very good \\
$61-80$ & Good \\
$41-60$ & Enough good \\
$21-40$ & Less good \\
$0-20$ & Not good \\
\hline
\end{tabular}

\section{RESULT AND DISCUSSION}

The data in this study were collected by using reading comprehension tests to measure critical thinking that contained 4 questions in the form of essays created using graphic organizer with an assessment using a 1-4 scale that was converted on a scale of 100 . The reading comprehension test results in this study relate to critical thinking skills possessed by students throughout the Pekanbaru city Tampan sub-district, which are described as follows: 
Table 3. Critical Thinking Ability in Elementary School Students, Tampan Sub-District

\begin{tabular}{cccccc}
\hline No & School Name & Respondents & F & P & Category \\
\hline 1 & SD Negeri 37 Pekanbaru & 25 Student & 750 & 30 & Less good \\
2 & SD Negeri 105 Pekanbaru & 20 Student & 644 & 32 & Less good \\
3 & SD Negeri 111 Pekanbaru & 20 Student & 381 & 19 & Not good \\
4 & SD Negeri 130 Pekanbaru & 18 Student & 469 & 26 & Less good \\
5 & SD Negeri 136 Pekanbaru & 18 Student & 463 & 26 & Less good \\
6 & SD Negeri 147 Pekanbaru & 14 Student & 344 & 25 & Less good \\
7 & SD Negeri 164 Pekanbaru & 21 Student & 375 & 18 & Not good \\
8 & SD Negeri 165 Pekanbaru & 15 Student & 525 & 35 & Less good \\
9 & SD Negeri 167 Pekanbaru & 21 Student & 319 & 15 & Not good \\
10 & SD Negeri 176 Pekanbaru & 15 Student & 356 & 24 & Less good \\
11 & SD Negeri 181 Pekanbaru & 20 Student & 338 & 17 & Not good \\
12 & SD Negeri 183 Pekanbaru & 22 Student & 469 & 21 & Less good \\
13 & SD Negeri 184 Pekanbaru & 18 Student & 619 & 34 & Less good \\
14 & SD Negeri 187 Pekanbaru & 18 Student & 206 & 12 & Not good \\
15 & SD Negeri 188 Pekanbaru & 15 Student & 294 & 20 & Not good \\
16 & SD Negeri 189 Pekanbaru & 19 Student & 350 & 18 & Not good \\
17 & SD Negeri 191 Pekanbaru & 9 Student & 156 & 17 & Not good \\
18 & SD Negeri 194 Pekanbaru & 10 Student & 181 & 18 & Not good \\
\hline
\end{tabular}

Based on data from the results of research on the ability of critical thinking elementary school students in Tampan Sub-District in table 3 can be seen that from 18 schools with a sample of 318 students there were 9 schools that received the category of 'less good', 9 schools that received the category of 'less good'. This is because of the 9 schools that get the less category get a score of 0 -20, the critical thinking ability of students through reading comprehension in the school is still not good because in learning in the classroom has not directed students towards critical thinking. While 9 schools that get a less category get a score of 21-40, the critical thinking ability possessed by students at the school also does not lead to critical thinking skills. The results of students' critical thinking skills in every school in the Tampan Sub-District in detail can be seen in the figure 1. 


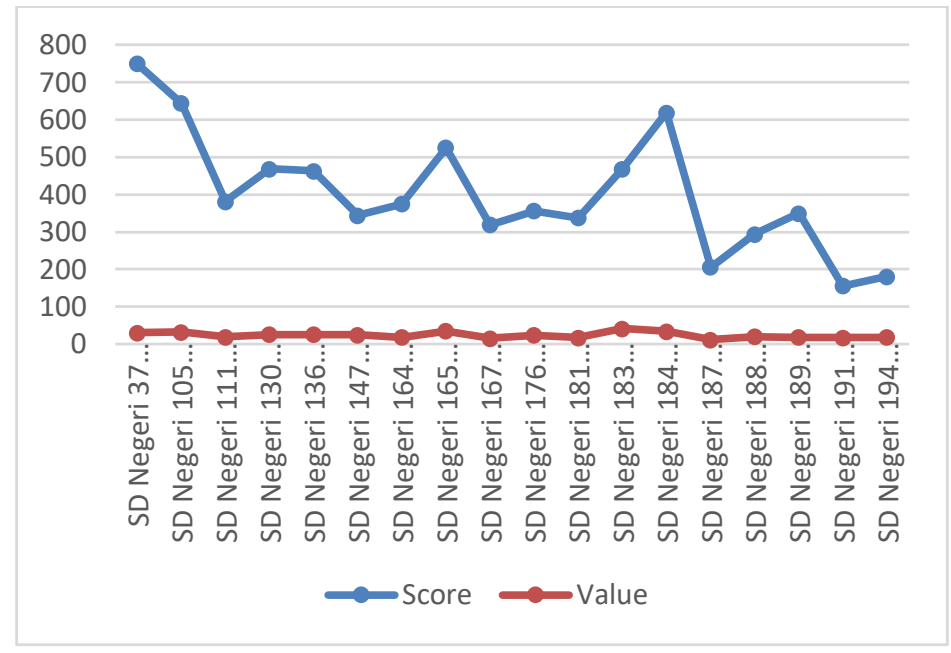

Figure 2. Students' Ability to Critical Thinking

Table 4. The Ability of Critical Thinking is Seen in Indicators

\begin{tabular}{clccc}
\hline No & Assessment Indicator & Sum & P & Category \\
\hline 1 & Identify the initial problem & 292 & 23 & Less good \\
2 & Understanding Reasoning & 258 & 20 & Not good \\
3 & Identify and interpret statements and ideas & 269 & 21 & Less good \\
4 & Identifying conclusions & 339 & 27 & Less good \\
& Average & 289.5 & 22.75 & Less good \\
\hline
\end{tabular}

Based on table 4, it is known that the overall value of the critical thinking ability of elementary school students in the sub-district of Tampan is 23 with a less category, the Indicator assessment of the Identify the initial problem score 23 is in the less category, Understanding reasoning gets a score of 20 with a not category, Identify and interpret statements and ideas got a score of 21 in the less category and Identifying conclusions received a score of 27 in the less category. Of the 4 critical thinking assessment indicators, the assessment indicated that gets the highest score is the Identifying conclusions indicator, while the assessment indicator that gets the lowest value is the understanding reasoning indicator. The results of critical thinking skills of elementary school students in Tampan Sub-District in detail can be seen in the diagram below: 


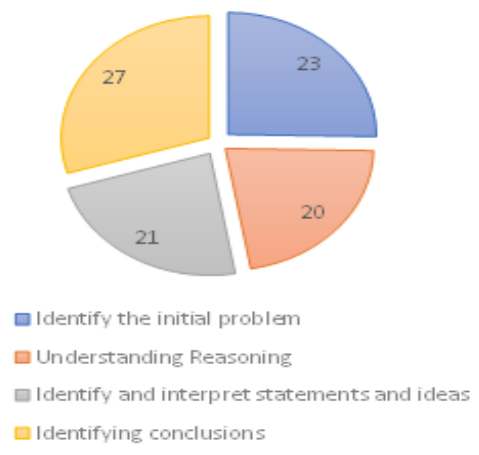

Figure 3. Capabilities Based on Critical Thinking Indicators

The ability of students in critical thinking is still in the less category, which means that the ability of students is still below standards, but does not produce critical thinking on a given problem. The Indonesian government has an effort to prepare students to face global competition by implementing a 2013 curriculum to support the 21 st-century learning process (Waslaluddin, et al, 2019). Expectations in developing critical thinking emphasized in the 2013 curriculum have not been reached to the maximum that is expected by looking at the results of research analyzes that show very low ability. Learning by the teacher has not contributed to critical thinking that must be developed by students. Developing critical thinking will automatically increase with age and gain more experience in the field of education with a lot of reading in school and outside the school environment (Khonamri \& Farzanegan, 2016). Critical thinking is believed to be one of the skills that must be taught to elementary school students to develop cognitive abilities and the extent to which students can be careful in connecting knowledge related to scientific disciplines (Hooks, 2010; Tsankov, 2017). Lack of teacher insight about practices and strategies in the classroom in teaching students critical thinking (Almulla, 2018) even though training has been held to train teachers in carrying out learning that focuses on critical thinking.

\section{CONCLUSION}

The critical thinking ability of students in the Tampan Sub-District is still in the very low category. Student competence is still not optimal by the teacher in teaching practice even though it has already been implemented in 2013 curriculum but it has not had the impact of change in developing critical thinking of elementary school students. For this reason, there is a need for more intensive training for teachers in classroom teaching practices to provide critical thinking. 


\section{Acknowledgments}

Thanks to the Dean of FKIP Riau University for providing research funding, those who have been involved in this research cannot be written one by one, but hopefully, become acts of worship in improving education.

\section{REFERENCES}

Almulla, M. (2018). Investigating Teachers' Perceptions Of Their Own Practices To Improve Students' Critical Thinking In Secondary Schools In Saudi Arabia. International Journal of Cognitive Research in Science, Engineering and Education (IJCRSEE), 6(3), 15-27. doi:10.5937/ijcrsee1803015A.

Abed, S., Davoudi, A. H. M., \& Hoseinzadeh, D. (2015). The Effect of Synectics Pattern on Increasing The Level of Problem Solving and Critical Thinking Skills in Students of Alborz Province. WALIA Journal, 31(S1), 110-118.

Anazifa, R. D., \& Djukri, D. (2017). Project-Based Learning and Problem-Based Learning: Are They Effective to Improve Student's Thinking Skills?. Jurnal Pendidikan IPA Indonesia, 6(2), 346-355.

Asmawati, E. Y. (2015). Lembar kerja siswa (LKS) menggunakan model guided inquiry untuk meningkatkan keterampilan berpikir kritis dan penguasaan konsep siswa. Jurnal Pendidikan Fisika, III(2), 1-16. doi: 10.24127/jpf.v3i1.13.

Bustami, Y., Syafruddin, D., \& Afriani, R. (2018). The Implementation Of Contextual Learning To Enhance Biology Students' Critical Thinking Skills. Jurnal Pendidikan IPA Indonesia, 7(4), 451-457. DOI: 10.15294/jpii.v7i4.11721.

Bustami, Y. (2009). Pendekatan Sains Teknologi Masyarakat (STM) untuk Meningkatkan Penguasaan Konsep dan Kemampuan Berpikir Kritis Siswa SMA pada Subtopik Pencemaran Air. Unpublished thesis. Bandung: Indonesia University of Education.

Carter, A. G., Creedy, D. K., \& Sidebotham, M. (2016). Efficacy of Teaching Methods Used to Develop Critical Thinking in Nursing and Midwifery Undergraduate Students: A Systematic Review of The Literature. Nurse education today, 40, 209-218.

Fisher, A. (2009). Berpikir Kritis: Sebuah Pengantar, Terj. dari "Critical Thinking: An Introduction" oleh Benyamin Hadinata. Jakarta: Penerbit Erlangga.

Grabe, W. \& Stoller, F. L. (2011). Teaching and researching reading (2nd ed.). Harlow, UK: Pearson Education.

Hooks, B. (2010). Teaching Critical Thinking: Practical Wisdom. London: Routledge. Retrieved from https://books.google.com.sa/books?id=tIfcYgE ACAAJ\&dq=Teaching + Critical + Thinking: + Practical + Wisdom\&hl=en\&sa $=$ X\&ved $=$ 0ahUKEw iTg863o9PdAhUHxxoKHfylAxwQ6AEIKTAA. 
Haryani, D. (2011). Pembiasaan berpikir kritis dalam belajar matematika sebagai upaya pembentukan individu yang kritis . Seminar Nasional Penelitian, Pendidikan dan Penerapan M (pp. 127-132). Yogyakarta: Fakultas MIPA, Universitas Negeri Yogyakarta.

Indrawatiningsih, N. (2018). Arguments in Critical Thinking Ability. First International Conference on Science, Mathematics, and Education, (ICoMSE 2017) (pp. 12-15). Malang: Atlantis Press.

Kemendikbud. (2018). Mendikbud Imbau Guru Terus Kembangkan Model Pembelajaran HOTS. Yogyakarta: Siaran Pers BKLM.

Kurniaman, O., \& Noviana, E. (2016). Metode Membaca SAS (Struktural Analitik Sintetik) dalam Meningkatkan Keterampilan Membaca Permulaan di Kelas I SDN 79 Pekanbaru. Primary: Jurnal Pendidikan Guru Sekolah Dasar,5(2), 149- 157.

Kurniaman, O., \& Charlina. (2018). Pembelajaran Membaca dengan Graphic Oraganizer di Sekolah Dasar. Pekanbaru: UR Press.

Khasanah, A. N., Widoretno, S., \& Sajidan, S. (2017). Effectiveness of Critical Thinking IndicatorBased Module in Empowering Student's Learning Outcome in Respiratory System Study Material. Jurnal Pendidikan IP A Indonesia, 6(1), 187-195.

Kurniaman, O., Noviana, E., Hermita, N., Maharani, A.S., \& Marwan, A. (2019). Development of Critical Thinking Test Instrument Reading Using The Graphic Organizer Media. Jurnal PAJAR (Pendidikan dan Pengajaran), 3(5), 974-802. DOI : http://dx.doi.org/10.33578/pjr.v3i5.7809.

Ku, K. Y. (2009). Assessing Students' Critical Thinking Performance: Urging for Measurements Using Multi-Response Format. Thinking skills and creativity, 4(1), 70-76.

Kurniaman, O., \& Noviana, E. (2013). Penerapan Kurikulum 2013 dalam Meningkatkan Keterampilan, Sikap, dan Pengetahuan. Primary: Jurnal Pendidikan Guru Sekolah Dasar, 6(2). 389-396.

Khonamri, F. \& Farzanegan, M. (2016). Literature-based extensive reading accompanied by reading logs: A case for developing critical thinking skills of English literature students. International Journal of Education, 9(1), 58-67. doi: dx.doi.org/10.17509/ije.v9i1.3719.

Munjiatun, et al. (2015). Kemampuan Mahasiswa PGSD FKIP UR dalam Keterampilan Membaca Pemahaman. Primary: Jurnal Pendidikan Guru Sekolah Dasar, 4(1), 12-20.

Malik, A., Setiawan, A., Suhandi, A., Permanasari, A., Samsudin, A., Safitri, D., Lisdiani, S.A.S., Sapriadil, S., \& Hermita, N. (2018). Using Hot Lab To Increase PreService Physics Teacher's Critical Thinking Skills Related To The Topic Of RLC Circuit. 4th International Seminar of Mathematics, Science and Computer Science Education. doi :10.1088/17426596/1013/1/012023. 
Murnaka, N. P., Almaisurie, Q., \& Arifin, S. (2019). Method On Guided Inquiry Learning To Improve Students' Critical Thinking Abilities In Facing The Industrial Revolution 4.0. INTERNATIONAL JOURNAL OF SCIENTIFIC \& TECHNOLOGY RESEARCH, 8(09),439 - 441.

Riduwan. (2015). Dasar-Dasar Statistika. Bandung: Alfabeta.

Sobkowiak, P. (2016). Critical thinking in the intercultural context: Investigating EFL textbooks. Studies in Second Language Learning and Teaching, 6 (4), 697-716. doi: 10.14746/ssllt.2016.6.4.7.

Sugiyono. 2015. Metode Penilitian kuantitatif Kualitatif dan R\&D. Bandung: Alfabeta.

Tsankov, N. (2017). Development of transversal competences in school education (a didactic interpretation). International Journal of Cognitive Research in Science, Engineering and Education (IJCRSEE), 5(2), 129-144. https:// doi.org/10.5937/IJCRSEE1702129T.

Trisdiono, H., Siswandari., Suryani, N., Joyoatmojo, S. (2019). Development of Multidisiplin Integrated Project-Based Learning Model To Improve Critical Thinking and Cooperation Skills. Jurnal Pendidikan Indonesia, 8(1), 9-20. DOI: 10.23887/jpiundiksha.v8i1.17401.

Wartono, W., Hudha, M. N., \& Batlolona, J. R. (2018). How Are The Physics Critical Thinking Skills of The Students Taught by Using InquiryDiscovery Through Empirical and Theorethical Overview?. Eurasia Journal of Mathematics, Science and Technology Education, 14(2), 691-697.

Waslaluddin, Rahman, E. F., Putra, R. R. J., \& Putra, B. L. (2019). Creative Learning Model As The Implementation Of Curriculum Learning 2013 To Achieve 21st Century Skills (Case Study: Elementary School In Bandung). International Journal Of Scientific \& Technology Research, 8(09), 675- 678. 